\title{
Chitosan oligosaccharides suppress LPS-induced IL-8 expression in human umbilical vein endothelial cells through blockade of p38 and Akt protein kinases
}

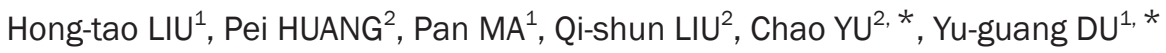 \\ ${ }^{1}$ Dalian Institute of Chemical Physics, Chinese Academy of Sciences, Dalian 116023, China; ${ }^{2}$ Institute of Life Sciences, Chongqing \\ Medical University, Chongqing 400016, China
}

\begin{abstract}
Aim: To investigate whether and how COS inhibited IL-8 production in LPS-induced human umbilical vein endothelial cells (HUVECs). Methods: RT-PCR, enzyme-linked immunosorbent assays (ELISA) and Western blotting were used to study IL-8 expression and related signaling pathway. Wound healing migration assays and monocytic cell adhesion analysis were used to explore the chemotactic and adhesive activities of HUVECs.

Results: COS 50-200 $\mathrm{mg} / \mathrm{mL}$ exerted a significant inhibitory effect on LPS $100 \mathrm{ng} / \mathrm{mL}-$ induced IL-8 expression in HUVECs at both the transcriptional and translational levels. In addition, COS 50-200 $\mathrm{mg} / \mathrm{mL}$ inhibited LPS-induced HUVEC migration and U937 monocyte adhesion to HUVECs in a concentration-dependent manner. Signal transduction studies suggest that COS blocked LPS-induced activation of nuclear factor-kB (NF-kB) and activator protein-1 (AP-1) as well as phosphorylation of p38 mitogen-activated protein kinase (MAPK) and phosphokinase Akt. Further, the over-expression of LPS-induced IL-8 mRNA in HUVECs was suppressed by a p38 MAPK inhibitor (SB203580, $25 \mu \mathrm{mol} / \mathrm{L}$ ) or a phosphatidylinositol 3-kinase (PI3K) inhibitor (LY294002, $50 \mu \mathrm{mol} / \mathrm{L}$ ).

Conclusion: COS inhibited LPS-induced IL-8 expression in HUVECs through the blockade of the p38 MAPK and PI3K/Akt signaling path-
\end{abstract} ways.

Keywords: anti-inflammatory agents; arteriosclerosis; lipopolysaccharides; endothelial cells; chemokine; MAPK; phosphatidylinositol 3-kinase; interleukin-8; NF-kappa B; chitosan oligosaccharides

Acta Pharmacologica Sinica (2011) 32: 478-486; doi: 10.1038/aps.2011.10

\section{Introduction}

Endothelial cells (ECs) located in the inner lining of the vascular space play a key role in maintaining essential physiological processes of the vasculature ${ }^{[1]}$. Serving as a barrier between the bloodstream and vascular wall, ECs are sensitive to pathological stimuli in the body. Once activated by extracellular mediators, ECs initiate a variety of inflammatory responses, which ultimately lead to the formation of cardiovascular diseases. Lipopolysaccharide (LPS), the major portion of the outer membrane of gram-negative bacteria, is a strong risk factor for vascular inflammation ${ }^{[2]}$. In the pathogenesis of infectious diseases, high levels of LPS directly lead to the occurrence of inflammatory responses elicited by ECs, including enhancement of endothelial permeability, secretion of chemokines and recruitment of circulating leukocytes ${ }^{[3]}$. Among these activities, LPS-induced interleukin-8 (IL-8)

\footnotetext{
* To whom correspondence should be addressed. E-mail yuchaom@163.com

Received 2010-11-14 Accepted 2011-02-14
}

expression should receive more attention for its substantial contribution to endothelial damage. As an early chemotactic signal in an inflammation reaction, IL-8 not only promotes the recruitment and adhesion of leucocytes but also mediates the complex activation of ECs ${ }^{[4,5]}$. Therefore, the inhibition of IL-8 expression in activated ECs has been considered as a potential therapeutic strategy against vascular inflammation.

Chitosan, the deacetylated derivative of chitin, is a linear polymer of $\beta$ - $(1,4)$-linked $D$-glucosamine ${ }^{[6]}$. Chitosan oligosaccharides (COS) are depolymerized products of chitosan by either chemical or enzymatic hydrolysis. As a cellulose-like biopolymer, COS are mainly produced from the exoskeleton of crustaceans and the cell walls of fungi and insects. Traditionally, COS were recommended as a healthy food in Asian countries for their diverse pharmacological effects such as antioxidant, antimicrobial, antitumor and antidiabetic activities ${ }^{[7-10]}$. In addition, recent studies suggest that COS have potential anti-inflammatory properties in vivo and in vitro. For example, Song et al reported that COS may be a potential immunoadjuvant for the treatment of metastatic tumors ${ }^{[11]}$. In the studies 
by Villiers et al, chitosan was found to regulate the balance of dendritic cell-induced IL-10 and IL-12 production $^{[12]}$. In addition, COS were shown to inhibit the production of nitric oxide, IL-6 and tumor necrosis- $\alpha$ (TNF- $\alpha$ ) in activated murine macrophages (RAW264.7 $)^{[13,14]}$. To the best of our knowledge, however, no studies have been performed to examine the effect of COS on LPS-induced IL-8 production in ECs, which may be helpful for determining the effect of COS in the treatment of vascular diseases.

Human umbilical vein endothelial cells (HUVECs) were demonstrated to be a useful in vitro model for studying the expression and regulation of inflammatory cytokines in response to exogenous stimuli ${ }^{[15]}$. The aim of this study was to explore whether and how COS inhibited IL-8 production in LPS-induced HUVECs. We evaluated the inhibition of IL-8 gene expression by COS in HUVECs at the transcriptional and translational levels. In addition, we assayed the suppressive effects of COS on LPS-induced HUVEC migration and U937 monocyte adhesion to HUVECs. To identify the underling mechanism(s) by which COS inhibits IL-8 over-production in HUVECs, we explored the roles of nuclear factor $\mathrm{\kappa B}(\mathrm{NF}-\mathrm{kB})$, p38 mitogen-activated protein kinase (MAPK) and phosphokinase Akt after LPS exposure.

\section{Materials and methods}

\section{Chemicals and reagents}

COS were prepared by our laboratory (the degree of deacetylation was over 95\%) and were free of endotoxin according to a limulus amebocyte lysate test ${ }^{[16]}$. The weight percentages of COS with degrees of polymerization (DP) of 2-6 in an oligomixture were $3.7 \%, 16.1 \%, 28.8 \%, 37.2 \%$, and $14.2 \%$, respectively. LPS from Escherichia coli and 3-(4,5-dimethylthiazol2-yl)-2,5-diphenyltetrazolium bromide (MTT) were obtained from Sigma (St Louis, MO, USA). The p38 MAPK inhibitor (SB203580) was purchased from Invitrogen Corporation (Carlsbad, CA, USA). The phosphatidylinositol 3-kinase (PI3K) inhibitor (LY294002), rabbit anti-NF-KB p65 polyclonal antibody and 2',7'-bis-(2-carboxyethyl)-5-(and-6)-carboxyfluorescein, acetoxymethyl ester (BCECF AM) were obtained from Beyotime Institute of Biotechnology (Jiangsu, China). Rabbit anti-p38 MAPK, anti-phospho-p38 (p-p38) MAPK, anti-Akt, anti-phospho-Akt (p-Akt), anti-c-Jun, anti-phospho-c-Jun (p-cJun) and anti-GAPDH polyclonal antibodies and horseradish peroxidase (HRP)-conjugated goat anti-rabbit IgG were purchased from Santa Cruz Biotechnology (Santa Cruz, CA, USA). Dulbecco's-modified Eagle's medium F12 (DMEMF12), RPMI-1640 medium and fetal bovine serum (FBS) were obtained from Gibco (Grand Island, NY, USA).

\section{Cell culture and drug treatment}

HUVECs were isolated from normal human umbilical cords, digested with $0.05 \%$ trypsin and $0.02 \%$ EDTA, and eluted with DMEM-F12. Cells were grown in DMEM-F12 containing 5 units/mL heparin, $30 \mu \mathrm{g} / \mathrm{mL}$ endothelial cell growth supplements, 100 units $/ \mathrm{mL}$ penicillin, 100 units/mL streptomycin and $10 \%$ FBS. At confluence, the cells were subcultured at a
1:3 ratio and then cultured in an atmosphere of 95\% air and 5\% $\mathrm{CO}_{2}$ at $37^{\circ} \mathrm{C}$. Passage 2-6 was chosen for experiments. The U937 monocytic cell line from Wuhan Institute of Cell Biology (Wuhan, China) was maintained in RMPI-1640 medium supplemented with $10 \%$ FBS and antibiotics.

After reaching sub-confluence, the HUVECs were pretreated with vehicle or COS (50-200 $\mu \mathrm{g} / \mathrm{mL}$ ) in DMEM-F12 with 1\% FBS for $24 \mathrm{~h}$. The cells were then washed with phosphatebuffered saline (PBS, pH 7.4) and exposed to $100 \mathrm{ng} / \mathrm{mL}$ of LPS for different time intervals.

\section{Cell viability assay}

HUVECs were plated at a density of $5 \times 10^{3}$ cells/well into 96-well plates containing $150 \mu \mathrm{L}$ of DMEM-F12 with $10 \%$ FBS and incubated overnight. Cells were treated with $150 \mu \mathrm{L}$ of COS (50-200 $\mu \mathrm{g} / \mathrm{mL})$ or LPS (100 ng/mL) in DMEM-F12 with $1 \%$ FBS for $24 \mathrm{~h}$. After the treatment, the cells were washed with PBS and incubated with MTT $(5 \mathrm{mg} / \mathrm{mL})$ in culture medium with $1 \%$ FBS. Following $3 \mathrm{~h}$ of incubation at $37^{\circ} \mathrm{C}$, the medium was discarded, and the formazan blue, which formed inside the cells, was dissolved in $100 \mu \mathrm{L}$ of DMSO. The optical density at $490 \mathrm{~nm}$ was determined with a Sunrise Remote Microplate Reader (Grodig, Austria). The cell viability of each well was presented as percentage of the control level.

\section{Reverse transcriptase-polymerase chain reaction (RT-PCR)}

Total RNA was extracted from HUVECs using TRIZOL (Takara, Dalian, China). Reverse transcription was performed in $10-\mu \mathrm{L}$ reaction mixtures containing $1 \mu \mathrm{g}$ total RNA, 2.5 units AMV reverse transcriptase, 25 pmol oligo-dT primer, $10 \mathrm{nmol}$ dNTP mixture and 20 units RNase inhibitor (Bioer, Hangzhou, China) at $42^{\circ} \mathrm{C}$ for $1 \mathrm{~h}$ and $95^{\circ} \mathrm{C}$ for $5 \mathrm{~min}$. To quantify the IL-8 mRNA expression in HUVECs, RT-PCR was carried out in $20-\mu \mathrm{L}$ PCR reaction mixtures containing $1 \mu \mathrm{L}$ cDNA reaction mixture, $10 \mathrm{nmol} \mathrm{dNTP}$ mixture, $10 \mathrm{pmol}$ sense and antisense primers, and 2 units BioReady rTaq polymerase (Bioer, Hangzhou, China). The following primers were used for mRNA amplification: IL-8 (292 bp, sense 5'-ATG ACT TCC AAG CTG GCC GTG GCT-3'; antisense 5'-TCT CAG CCC TCT TCA AAA ACT TCT C-3') and GAPDH (230 bp, sense 5'-CTC TCT GCT CCT CCT GTT CGA CAG-3'; antisense 5'-GTG GAA TCA TAT TGG AAC ATG T-3'). The thermal cycling program was as follows: $4 \mathrm{~min}$ at $94{ }^{\circ} \mathrm{C}$ for initial denaturation and 30 cycles of $30 \mathrm{~s}$ at $94^{\circ} \mathrm{C}, 30 \mathrm{~s}$ at $60^{\circ} \mathrm{C}$ for IL- 8 and $54^{\circ} \mathrm{C}$ for GAPDH, and $30 \mathrm{~s}$ at $72{ }^{\circ} \mathrm{C}$. For PCR product analysis, 6 $\mu \mathrm{L}$ of each reaction mixture was electrophoresed on a $1.5 \%$ agarose gel containing $1 \%$ GoldView ${ }^{\mathrm{TM}}$. Band intensities were analyzed with ImageJ software (NIH, USA) and are presented as a percentage of GAPDH expression.

\section{Enzyme-linked immunosorbent assay (ELISA) for IL-8}

The concentration of IL- 8 in the culture medium was detected with an ELISA kit according to the manufacturer's instructions (R\&D Systems, Minneapolis, USA). Briefly, $100 \mu \mathrm{L}$ of experimental supernatants or IL-8 standard dilution was added into a microplate pre-coated with anti-IL-8 human monoclonal 
antibody and incubated for $1.5 \mathrm{~h}$ at $37^{\circ} \mathrm{C}$. The microplate was then washed, reacted with detection antibody for $1 \mathrm{~h}$ and washed again. Next, horse radish peroxidase (HRP) was added for a 30-min incubation before another wash and subsequent incubation with the substrate solution for $15 \mathrm{~min}$. Finally, the reaction was stopped with $2 \mathrm{~mol} / \mathrm{L} \mathrm{H}_{2} \mathrm{SO}_{4}$ and the absorbance of each well was measured at $450 \mathrm{~nm}$ using a Sunrise Remote Microplate Reader (Grodig, Austria). The concentration of IL- $8(\mathrm{pg} / \mathrm{mL})$ was acquired by comparing the absorbance values to those obtained from a standard curve.

\section{Wound healing migration assay}

HUVECs were seeded at a density of $10^{5}$ cells/well in 24-well plates in DMEM-F12 with 10\% FBS. After reaching subconfluency, the cells were pretreated with COS as described above. Subsequently, the cell monolayer was scratched with a pipette tip to obtain a "wounded" zone. The medium and dislodged cells were aspirated, and then the remaining cells were exposed to LPS $(100 \mathrm{ng} / \mathrm{mL})$ for $12 \mathrm{~h}$. After incubation, the cells were washed with PBS, fixed with $4 \%$ paraformaldehyde, and stained with hematoxylin and eosin. Cell migration was observed, and photos were taken using a phase contrast microscope (Wetzlar, Germany). The number of migrated cells in the wounded area under different experimental conditions was counted using a pre-defined frame.

\section{Monocytic cell adhesion assay}

HUVECs were grown in DMEM-F12 with $10 \%$ FBS at a density of $10^{5}$ cells/well in 24-well plates. After growth to subconfluence, the cells were pretreated with COS as described above. Following the pretreatment, the cells were washed with PBS and exposed to LPS $(100 \mathrm{ng} / \mathrm{mL})$ for $4 \mathrm{~h}$. U937 monocytes were incubated in RPMI-1640 medium containing $10 \% \mathrm{FBS}$ and $10 \mu \mathrm{mol} / \mathrm{L}$ of fluorescent dye BCECF-AM at $37^{\circ} \mathrm{C}$ for $1 \mathrm{~h}$. Fluorescence-labeled U937 cells were washed with PBS twice and seeded at a density of $5 \times 10^{4}$ cells/well onto HUVECs treated with COS and/or LPS. After incubation at $37^{\circ} \mathrm{C}$ for $1 \mathrm{~h}$, non-adherent U937 cells were removed by gentle washing with PBS, and the images of random fields were captured using a Leica DMRX microscope (Wetzlar, Germany). The fluorescent intensity of each image was measured with Image-Pro Plus 6.0 software (Media Cybernetics, USA).

\section{Preparation of cell lysates}

Nuclear and cytoplasmic fractions were separated using a nuclear and cytoplasmic protein extraction kit (Beyotime, Jiangsu, China). Briefly, cells were washed with ice-cold PBS (pH 7.4), harvested and resuspended in $200 \mu \mathrm{L}$ lysis buffer A $(10 \mathrm{mmol} / \mathrm{L}$ Hepes with $\mathrm{pH} 7.9,10 \mathrm{mmol} / \mathrm{L} \mathrm{KCl}, 0.1$ $\mathrm{mmol} / \mathrm{L}$ EDTA, $1 \mathrm{mmol} / \mathrm{L}$ dithiothreitol, 0.4\% Igepal CA-630, $5 \mu \mathrm{mol} / \mathrm{L}$ leupeptin, $2 \mu \mathrm{mol} / \mathrm{L}$ pepstatin A, $1 \mu \mathrm{mol} / \mathrm{L}$ aprotinin and $1 \mathrm{mmol} / \mathrm{L}$ phenylmethylsulfonyl fluoride). Following a violent vortex, the obtained lysates were incubated for $10 \mathrm{~min}$ on ice and centrifuged at $12000 \times \mathrm{g}$ for $5 \mathrm{~min}$ at $4{ }^{\circ} \mathrm{C}$. The supernatant, consisting of the cytoplasmic fraction, was aliquoted for analysis. The pellets were resuspended in $50 \mu \mathrm{L}$ nuclear extraction buffer B ( 20 mmol/L Hepes with $\mathrm{pH} 7.9,0.4$ $\mathrm{mol} / \mathrm{L} \mathrm{NaCl}, 1 \mathrm{mmol} / \mathrm{L}$ EDTA, $1 \mathrm{mmol} / \mathrm{L}$ dithiothreitol and $1 \mathrm{mmol} / \mathrm{L}$ phenylmethylsulfonyl fluoride) and then agitated for $30 \mathrm{~min}$ at $4{ }^{\circ} \mathrm{C}$. After centrifugation at $12000 \times g$ for $10 \mathrm{~min}$, the supernatant containing nuclear extracts was collected. For isolation of total cell extracts, the cells were lysed in RIPA lysis buffer $(50 \mathrm{mmol} / \mathrm{L}$ Tris with $\mathrm{pH} 7.4,150 \mathrm{mmol} / \mathrm{L} \mathrm{NaCl}, 1 \%$ Triton X-100, $1 \%$ sodium deoxycholate, $0.1 \%$ sodium dodecyl sulfate and $0.05 \mathrm{mmol} / \mathrm{L}$ EDTA) for $15 \mathrm{~min}$ on ice. The lysates were centrifuged at $12000 \times g$ for $10 \mathrm{~min}$ at $4{ }^{\circ} \mathrm{C}$, and the supernatants were collected. Protein content of extracted samples was measured using a bicinchoninic acid protein assay kit (BioMed, Beijing, China). All samples were stored at $-80{ }^{\circ} \mathrm{C}$ until further analysis.

\section{Western blot analysis}

To evaluate the expression of target proteins, cell lysates were boiled in $5 \times$ loading buffer $(125 \mathrm{mmol} / \mathrm{L}$ Tris $\cdot \mathrm{HCl}, \mathrm{pH} 6.8,10 \%$ SDS, $8 \%$ dithiothreitol, $50 \%$ glycerol and $0.5 \%$ bromochlorophenol blue) for $10 \mathrm{~min}$. Equal amounts of protein $(50 \mu \mathrm{g})$ were separated on $8 \%-12 \%$ SDS-polyacrylamide gels and transferred to $0.45 \mu \mathrm{m}$ polyvinylidene fluoride membranes. The membranes were blocked with 5\% skim milk in PBS with $0.1 \%$ Tween 20 (PBST) for $1 \mathrm{~h}$ and incubated with primary antibodies overnight at $4{ }^{\circ} \mathrm{C}$, including NF-KB p65 (1:250), phosphorylated (p)-p38 (1:500), p38 (1:500), p-Akt (1:1000), Akt (1:1000), c-Jun(1:1000), p-c-Jun (1:1000) and GAPDH (1:1000). Then the membranes were washed with PBST and incubated with HRP-conjugated secondary antibodies for $1 \mathrm{~h}$ at room temperature. After the final wash, specific protein bands were visualized using enhanced chemiluminescence reagents (ECL), and densitometric analysis was performed with the use of a PDI Imageware System (Bio-Rad, Hercules, CA, USA).

\section{Statistics}

Statistical analyses were performed using SPSS 10.0 package (SPSS Inc, Chicago, IL, USA). Data are represented as means \pm SD. One-way ANOVA and Student's $t$-tests were performed to determine statistical significance. Values with $P<0.05$ were considered significant.

\section{Results}

COS fail to decrease the cell viability of HUVECs

Because COS have been reported to stimulate the growth of normal cells and to induce tumor cell apoptosis ${ }^{[17,18]}$, their effect on the cell viability of HUVECs was assessed. After treatment with COS $(50,100$, and $200 \mu \mathrm{g} / \mathrm{mL})$ or LPS (100 $\mathrm{ng} / \mathrm{mL}$ ) alone for $24 \mathrm{~h}$, no difference was observed compared to the vehicle-treated group (data not shown), indicating that both COS and LPS at the above concentrations failed to cause cytotoxic effects on HUVECs.

COS inhibit LPS-induced IL-8 expression in HUVECs at the transcriptional and translational levels

To investigate whether COS are capable of inhibiting LPSinduced IL-8 expression in HUVECs at the transcriptional 
level, the cells were pretreated with COS as described previously and then exposed to LPS (100 ng/mL) for $4 \mathrm{~h}$. As indicated in Figure $1 \mathrm{~A}$, stimulation with LPS caused a $333.7 \% \pm 36.7 \%$ increase in the mRNA level of IL-8 compared to the vehicle-treated group $(P<0.01)$. COS $(100$ and 200 $\mu \mathrm{g} / \mathrm{mL}$ ) pretreatment for $24 \mathrm{~h}$ significantly inhibited LPSinduced over-expression of IL-8 mRNA $(48.9 \% \pm 2.9 \%$ and $47.7 \% \pm 4.3 \%$ of that of the LPS-treated group, respectively, $P<0.01)$.
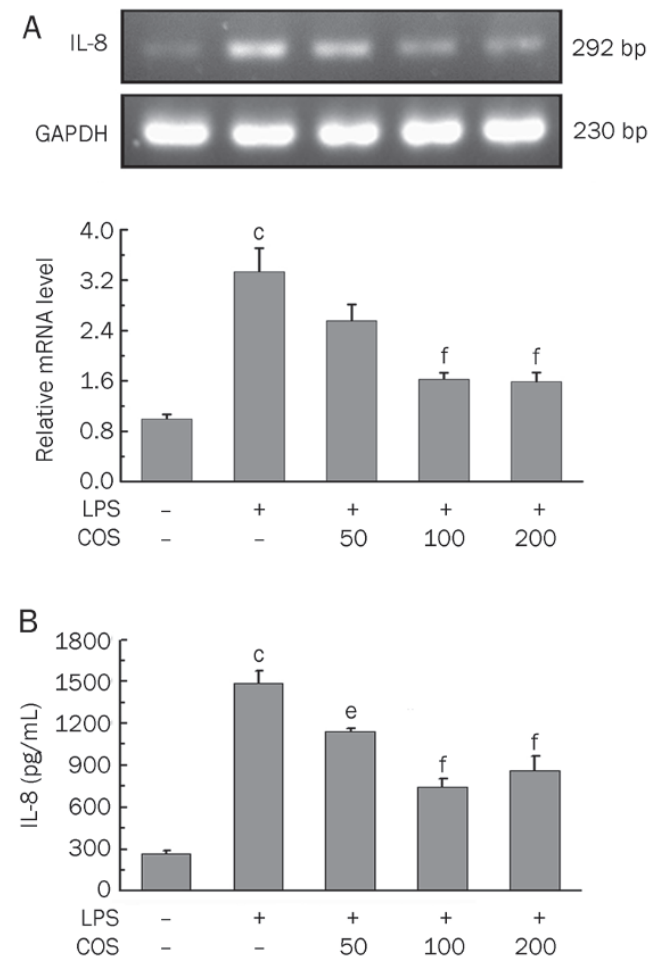

Figure 1. Inhibition of LPS-induced IL-8 expression in HUVECs by COS at transcription and translation levels. (A) Cells were pretreated with cos (50, 100, and $200 \mu \mathrm{g} / \mathrm{mL}$ ) for $24 \mathrm{~h}$ and then exposed to LPS (100 ng/mL) for $4 \mathrm{~h}$. After treatment, the IL-8 mRNA level was determined by RT-PCR analysis as described in Materials and methods. (B) Cells were pretreated with $\operatorname{COS}(50,100$, and $200 \mu \mathrm{g} / \mathrm{mL})$ for $24 \mathrm{~h}$ and then exposed to LPS $(100 \mathrm{ng} / \mathrm{mL})$ for $8 \mathrm{~h}$. After treatment, the concentration of IL-8 in culture medium was determined by ELISA analysis as described in Materials and methods. Data are expressed as means $\pm \mathrm{SD}(n=3)$. ${ }^{\mathrm{c}} P<0.01$ compared to the vehicle-treated group; ${ }^{e} P<0.05,{ }^{f} P<0.01$ compared to the LPS-treated group.

The effect of COS on LPS-induced IL-8 secretion in HUVECs was also determined using ELISAs. As expected, we found that the secretion of IL-8 in the supernatant fraction of HUVECs was significantly increased by an LPS $(100 \mathrm{ng} / \mathrm{mL})$ challenge for $8 \mathrm{~h}(550.5 \% \pm 33.5 \%$ of the vehicle-treated group, $P<0.01)$ (Figure 1B), whereas pretreatment with COS $(50,100$, and $200 \mu \mathrm{g} / \mathrm{mL})$ markedly reduced the IL-8 concentration to $77.0 \% \pm 1.4 \%(P<0.05), 50.0 \% \pm 3.8 \%(P<0.01)$ and $58.3 \% \pm 6.4 \%$ $(P<0.01)$ of that of the LPS-treated group, respectively.

\section{COS suppress LPS-induced HUVEC migration}

To evaluate the suppressive effect of COS on LPS-induced HUVEC migration, a wound-healing method was used with some modifications ${ }^{[19]}$. As shown in Figure 2, after exposure to LPS (100 ng/mL) for $12 \mathrm{~h}$, the number of cells migrating into the "wounded" zone was increased to $261.0 \% \pm 20.9 \%$ of the vehicle-treated group $(P<0.01)$, whereas COS (50, 100 and 200 $\mu \mathrm{g} / \mathrm{mL}$ ) pretreatment for $24 \mathrm{~h}$ led to a concentration-dependent decrease in HUVEC migration $(50 \mu \mathrm{g} / \mathrm{mL}, 89.5 \% \pm 12.5 \%$, $P=0.42 ; 100 \mu \mathrm{g} / \mathrm{mL}, 69.8 \% \pm 4.2 \%, P<0.05 ; 200 \mu \mathrm{g} / \mathrm{mL}$, $62.5 \% \pm 1.9 \%, P<0.05$, vs the LPS-treated group).

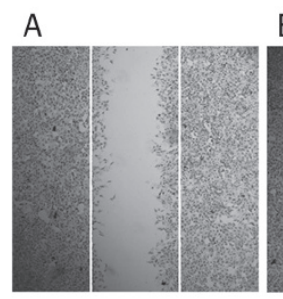

B
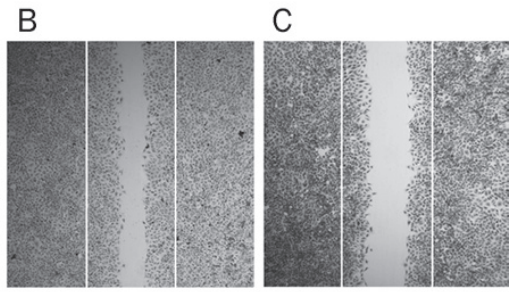

D

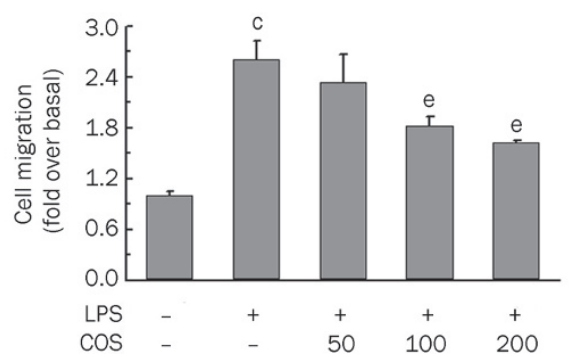

Figure 2. Suppressive effect of COS on LPS-induced HUVEC migration. (A) After wounding of the HUVEC monolayer, cells were stimulated with vehicle for $12 \mathrm{~h}$. (B) After wounding of the HUVEC monolayer, cells were stimulated with LPS $(100 \mathrm{ng} / \mathrm{mL})$ for $12 \mathrm{~h}$. (C) After pretreatment with $\cos (200 \mu \mathrm{g} / \mathrm{mL})$ for $24 \mathrm{~h}$, the HUVEC monolayer was wounded and then exposed to LPS $(100 \mathrm{ng} / \mathrm{mL})$ for $12 \mathrm{~h}$. (D) HUVEC migration was presented as a percentage of the vehicle-treated group. Cells migrated into the denuded area were counted as described in Materials and methods. Data are expressed as means \pm SD. $\quad(n=3) .{ }^{c} P<0.01$ compared to the vehicle-treated group; ${ }^{\mathrm{e}} P<0.05$ compared to the LPS-treated group.

\section{COS inhibit U937 cell adhesion to LPS-induced HUVECs}

To determine whether the inhibition of IL-8 expression by COS in LPS-induced HUVECs was associated with a decrease in monocyte adhesion, we assessed U937 cell adhesion to HUVECs challenged by LPS. There was a $348.2 \% \pm 43.5 \%$ increase in the rate of U937 cell adhesion to HUVECs after LPS exposure (100 ng/mL) for $4 \mathrm{~h}$ compared to the vehicletreated group $(P<0.01)$ (Figure 3$)$. When HUVECs were pretreated with COS for $24 \mathrm{~h}$ before exposure to LPS, the number of adherent U937 cells was strikingly reduced $(50 \mu \mathrm{g} / \mathrm{mL}$, $60.8 \% \pm 3.6 \%, P<0.05 ; 100 \mu \mathrm{g} / \mathrm{mL}, 41.3 \% \pm 4.1 \%, P<0.01 ; 200 \mu \mathrm{g} /$ $\mathrm{mL}, 37.2 \% \pm 1.9 \%, P<0.01$ vs the LPS-treated group). 
A

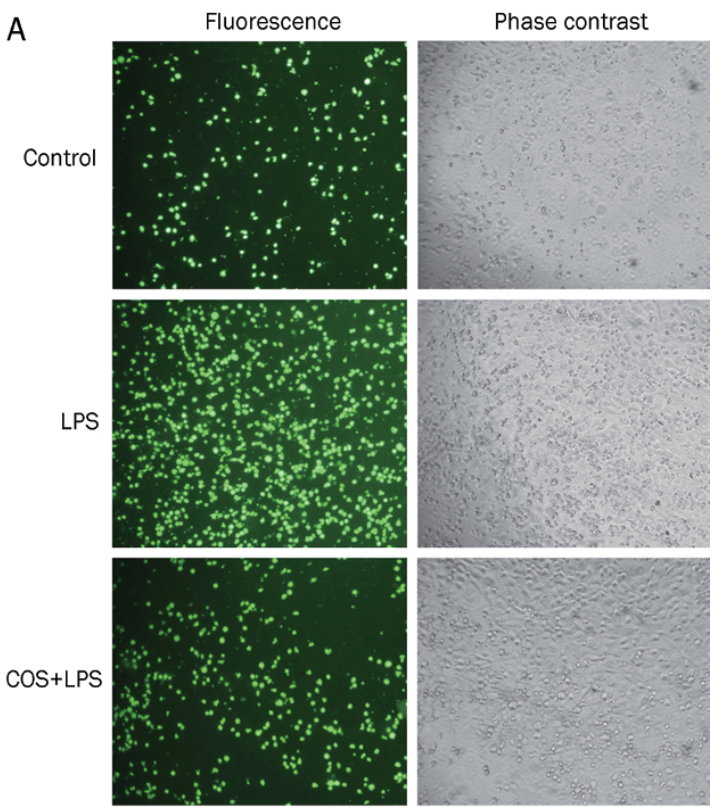

B

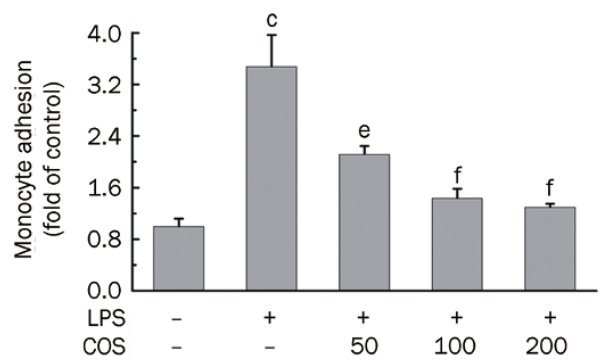

Figure 3. Inhibitory effect of COS on U937 cell adhesion to LPSinduced HUVECs. Cells were pretreated with $\operatorname{COS}(50,100$, and 200 $\mu \mathrm{g} / \mathrm{mL}$ ) or vehicle for $24 \mathrm{~h}$, exposed to LPS (100 ng/mL) for $4 \mathrm{~h}$ and then incubated with fluorescent-labeled U937 cells for $1 \mathrm{~h}$. (A) Representative fluorescence and phase contrast images of HUVECs were shown. (B) Monocyte adhesion was presented as a percentage of total fluorescent intensity of the vehicle-treated group. Data are expressed as means $\pm S D$. $(n=3) .{ }^{c} P<0.01$ compared to the vehicle-treated group; ${ }^{\mathrm{e}} P<0.05,{ }^{\mathrm{f}} P<0.01$ compared to the LPS-treated group.

CoS display a blocking effect on LPS-induced NF-KB and AP-1 translocation into the nuclei of HUVECs

Because increased expression of IL-8 is known to be associated with the activation of NF-KB and AP- ${ }^{[20,21]}$, we tested the inhibitory effects of COS on LPS-induced nuclear translocation of both transcription factors in HUVECs. As shown in Figure $4 \mathrm{~A}$, in comparison to the vehicle-treated group, LPS $(100 \mathrm{ng} / \mathrm{mL})$ exposure for $4 \mathrm{~h}$ stimulated NF-kB translocation into the nucleus of HUVECs, as indicated by an increased protein level of NF-KB p65 in the nucleus $(187.5 \% \pm 16.9 \%, P<0.01)$. However, this translocation was remarkably down-regulated by COS pretreatment for $24 \mathrm{~h}(50 \mu \mathrm{g} / \mathrm{mL}, 46.6 \% \pm 6.5 \%, P<0.01$; $100 \mu \mathrm{g} / \mathrm{mL}, 8.8 \% \pm 1.1 \%, P<0.01 ; 200 \mu \mathrm{g} / \mathrm{mL}, 20.1 \% \pm 1.2 \%$, $P<0.01$, vs the LPS-treated group). In parallel, COS pretreatment also suppressed LPS-induced AP-1 activation in the
A
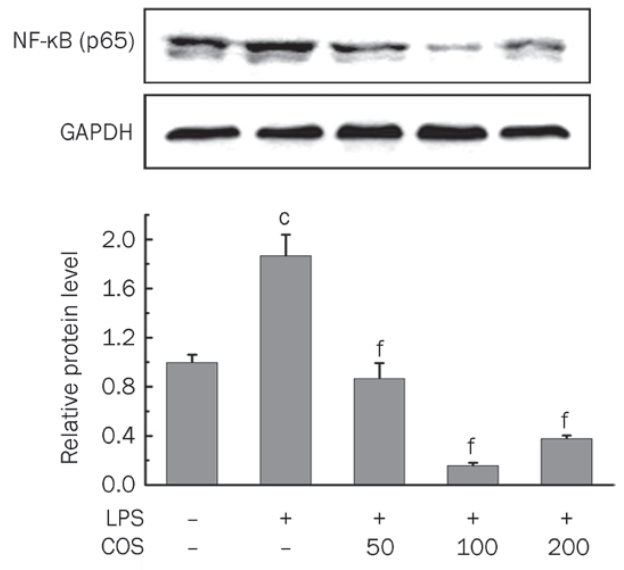

B
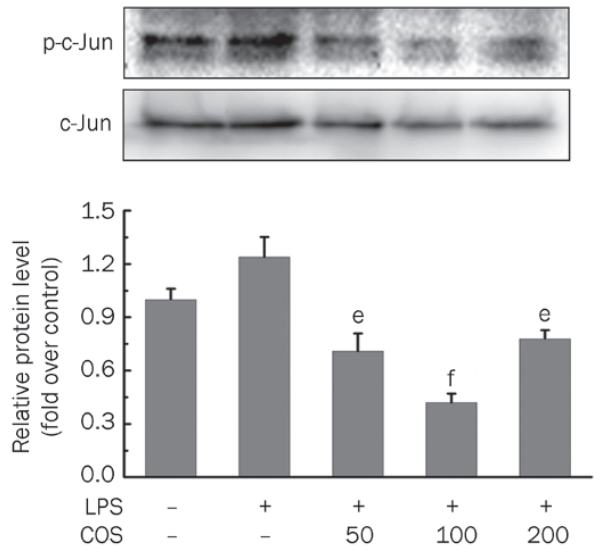

Figure 4. Blocking effect of COS on LPS-induced NF-KB and AP-1 translocation into nucleus of HUVECs. (A) Relative protein levels of NF$K B$ in nucleus of HUVECs. (B) Relative protein levels of AP-1 in nucleus of HUVECs. Cells were pretreated with $\operatorname{COS}(50,100$, and $200 \mu \mathrm{g} / \mathrm{mL})$ for $24 \mathrm{~h}$ and then exposed to LPS $(100 \mathrm{ng} / \mathrm{mL})$ for $4 \mathrm{~h}$. After treatment, nuclear and cytoplasmic fractions were analyzed for detection of NF-KB by Western blot analysis as described in Materials and methods. Data are representative of three experiments (mans $\pm S D$ ). ${ }^{c} P<0.01$ compared to the vehicle-treated group; ${ }^{\mathrm{e}} P<0.05,{ }^{\mathrm{f}} P<0.01$ compared to the LPS-treated group.

nucleus of HUVECs, which was presented as the relative expression of c-Jun, a major component of AP-1 $(50 \mu \mathrm{g} / \mathrm{mL}$, $56.9 \% \pm 8.0 \%, P<0.05 ; 100 \mu \mathrm{g} / \mathrm{mL}, 34.0 \% \pm 4.1 \%, P<0.01 ; 200$ $\mu \mathrm{g} / \mathrm{mL}, 63.1 \% \pm 3.9 \%, P<0.05$, vs the LPS-treated group) (Figure $4 \mathrm{~B})$. These results suggest that COS effectively inhibited LPSinduced NF-KB and Ap-1 activation in HUVECs.

COS inhibit LPS-induced over-expression of phosphorylated p38 MAPK and Akt in HUVECs

Next, we determined the effect of COS on the p38 MAPK signaling pathway, which is involved in the regulation of upstream gene expression in HUVECs ${ }^{[22]}$. The results in Figure $5 \mathrm{~A}$ show that LPS $(100 \mathrm{ng} / \mathrm{mL})$ exposure for $10 \mathrm{~min}$ induced a rapid increase in p-p38 protein levels in HUVECs $(120.6 \% \pm 14.5 \%$ of the vehicle-treated group, $P<0.01)$. After 
A
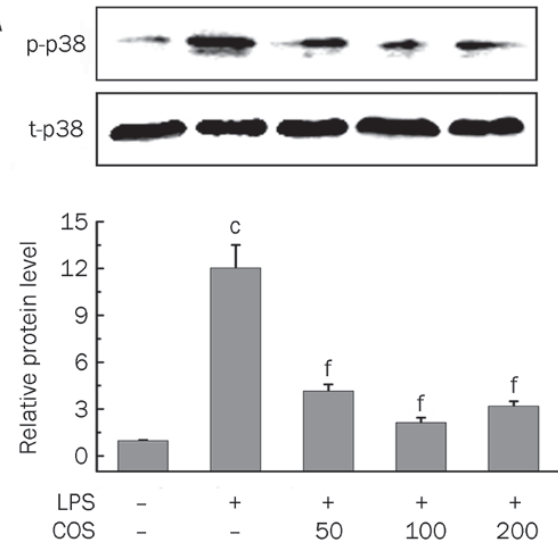

B
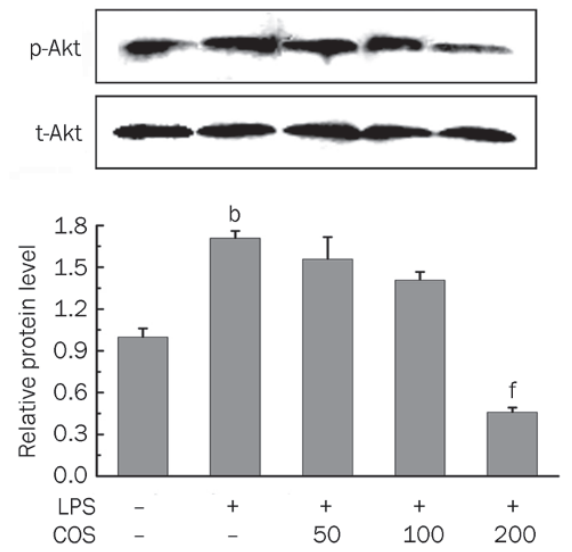

Figure 5. Inhibitory effect of COS on LPS-induced over-expression of phosphorylated p38 MAPK (A) and Akt (B) in HUVECs. Cells were pretreated with $\operatorname{COS}(50,100$, and $200 \mu \mathrm{g} / \mathrm{mL})$ for $24 \mathrm{~h}$ and then exposed to LPS (100 ng/mL) for 10 min for p38 detection and for $1 \mathrm{~h}$ for Akt detection. After treatment, cell lysates were extracted and the protein levels of phosphorylated p38 (p-p38) MAPK, total p38 (t-p38) MAPK, phosphorylated Akt ( $\mathrm{p}-\mathrm{Akt}$ ) and total Akt (t-Akt) were determined by Western blot analysis as described in Materials and methods. Data are representative of three experiments (mans \pm SD). ${ }^{b} P<0.05,{ }^{c} P<0.01$ compared to the vehicle-treated group; ${ }^{f} P<0.01$ compared to the LPStreated group.

pretreatment with COS at concentrations of 50, 100, and 200 $\mathrm{\mu g} / \mathrm{mL}$ for $24 \mathrm{~h}$, the level of $\mathrm{p}-\mathrm{p} 38$ was reduced to $34.6 \% \pm 3.5 \%$ $(P<0.01), 17.8 \% \pm 2.5 \%(P<0.01)$ and $26.6 \% \pm 2.4 \%(P<0.01)$ of that of the LPS-treated group, respectively.

Several studies have reported the activation of the phosphatidylinositol 3-kinase (PI3K)/ Akt pathway and its contribution to the up-regulated production of inflammatory cytokines in activated endothelial cells ${ }^{[23]}$. Thus, we analyzed the effect of COS on LPS-induced PI3K/Akt activation in HUVECs. As shown in Figure 5B, the level of p-Akt in HUVECs was increased to $171.5 \% \pm 10.8 \%$ of that of the vehicletreated group $(P<0.05)$ after LPS $(100 \mathrm{ng} / \mathrm{mL})$ exposure for $1 \mathrm{~h}$. COS pretreatment for $24 \mathrm{~h}$ failed to inhibit LPS-induced Akt phosphorylation from 50 to $100 \mu \mathrm{g} / \mathrm{mL}$. However, COS at 200 $\mu \mathrm{g} / \mathrm{mL}$ exhibited a significant inhibition of p-Akt $(26.6 \% \pm 1.9 \%$ of that of the LPS-treated group, $P<0.01)$.

p38 MAPK and PI3K inhibitors suppress LPS-induced IL-8 mRNA levels in HUVECs

A p38 inhibitor, SB203580, and a PI3K inhibitor, LY294002, were used in this study to determine whether COS inhibited LPS-induced IL-8 expression in HUVECs through the blockade of the p38 MAPK and PI3K/Akt signaling pathways. When cells were pretreated with SB203580 $(25 \mu \mathrm{mol} / \mathrm{L})$ or LY294002 (50 $\mathrm{\mu mol} / \mathrm{L})$ for $1 \mathrm{~h}$ and then challenged with LPS (100 ng/mL) for $4 \mathrm{~h}$, LPS-induced expression of IL-8 mRNA was reduced to $52.4 \% \pm 2.6 \%(P<0.01)$ and $56.4 \% \pm 3.4 \%(P<0.05)$, respectively, in comparison to the LPS-treated group (Figure $6 \mathrm{~A}$ and $6 \mathrm{~B}$ ). Additionally, treatment with the inhibitors alone had no effect on IL-8 mRNA expression in HUVECs that were not treated with LPS. These results indicate that the p38 MAPK and PI3K/Akt pathways are required for LPS-induced
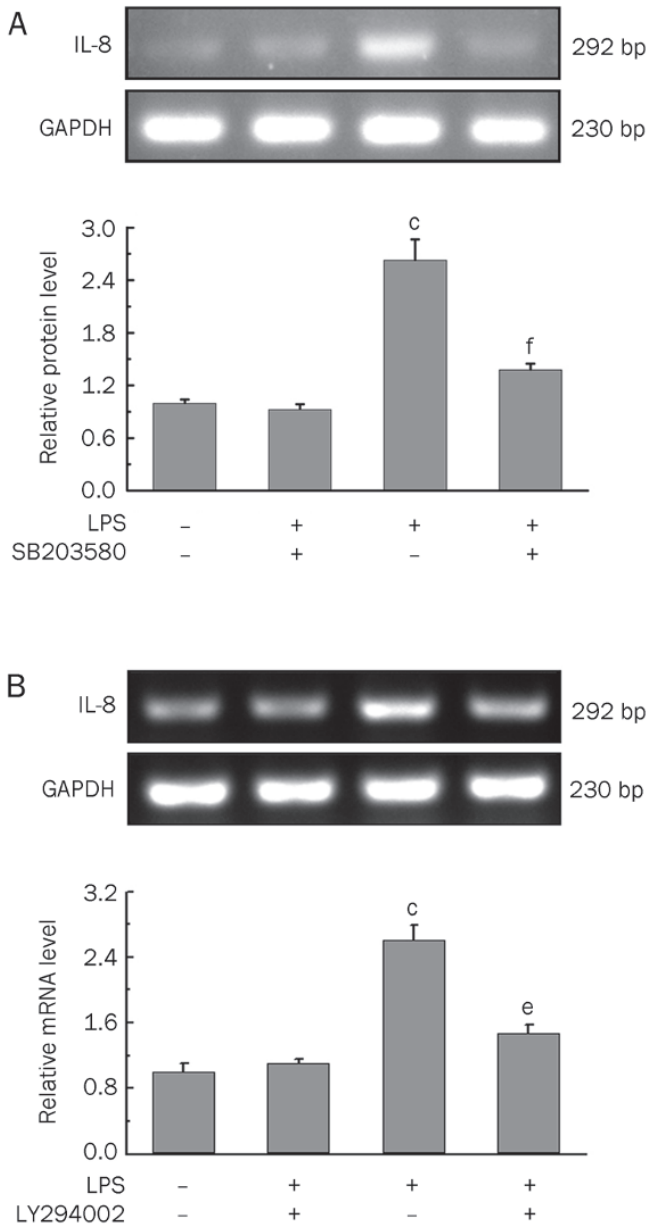

Figure 6. Suppressive effects of p38 MAPK inhibitor, SB203580 (A) and PI3K inhibitor, LY294002 (B) on LPS-induced IL-8 mRNA level in HUVECs. Cells were pretreated with SB203580 (25 $\mu \mathrm{mol} / \mathrm{L})$ or LY294002 (50 $\mu \mathrm{mol} / \mathrm{L})$ for $1 \mathrm{~h}$ and then exposed to LPS $(100 \mathrm{ng} / \mathrm{mL})$ for $4 \mathrm{~h}$. After treatment, the mRNA expression of IL-8 was analyzed by RT-PCR as described in Materials and methods. Data are representative of three experiments (mans $\pm \mathrm{SD}$ ). ${ }^{\mathrm{c}} P<0.01$ compared to the vehicle-treated group; ${ }^{\mathrm{e}} P<0.05,{ }^{\mathrm{f}} P<0.01$ compared to the LPS-treated group. 
IL-8 expression at the mRNA level.

\section{Discussion}

Endothelial dysfunction, the early stage of vasculopathy, is closely related to the vascular inflammatory process, and excessive secretion of pro-inflammatory cytokines released by damaged ECs may indicate a dysregulation of the host defense against invasive stimuli in vivo ${ }^{[22]}$. This view is supported by Papadopoulou et al and by Seino et $a l^{[24,25]}$, who found that over-expression of IL-8, IL-6, monocyte chemoattractant protein-1 (MCP-1) and other chemokines occurred in ECs and the intima of atherosclerotic lesions. Therefore, the inhibition of IL-8 and other mediators in activated ECs through drugs or specific nutrients might be of great benefit in the maintenance of endothelial homeostasis and the prevention of vascular diseases. Several intervention studies have shown that COS can regulate immune responses by decreasing the production of pro-inflammatory cytokines ${ }^{[12-14]}$. Our results provide the first evidence that COS inhibit the production of IL-8 in LPSinduced HUVECs through the blockade of the p38 MAPK and PI3K/Akt signaling pathways.

As a key mediator in acute inflammatory responses, IL-8 can be produced in ECs stimulated by IL-1 $\beta$, TNF- $\alpha$, LPS, and other infectious agents ${ }^{[23,26,27]}$. In this context, drugs with antiinflammatory activities have been investigated to ameliorate endothelial damage by limiting the synthesis and release of IL-8. For example, ghrelin, a newly discovered hormone, was verified to inhibit TNF-a-induced IL-8 production in ECs ${ }^{[28]}$. Moreover, ciprofloxacin, one of the quinolone antibiotics, displayed a suppressive effect on IL-8 mRNA expression in $E C s^{[29]}$. In this study, we determined the mRNA expression and protein secretion of IL-8 in LPS-induced HUVECs. We found that pre-incubation with COS ameliorated the elevated production of IL- 8 by LPS stimulation. Because incubation of COS (50-200 $\mu \mathrm{g} / \mathrm{mL})$ alone for $24 \mathrm{~h}$ showed no inhibitory effect on the cell viability of HUVECs, it was apparent that the inhibition of IL-8 production by COS pretreatment was not due to a decrease in cell numbers but to a down-regulation in the cellular production of IL-8. The data support our hypothesis that COS may exert a blunting effect on LPS-induced IL-8 production in ECs.

In the process of vascular inflammation, chemotactic stimuli direct the migration of leukocytes toward damaged vessel walls and the subsequent adhesion to ECs ${ }^{[30]}$. In addition, activated ECs by themselves can migrate to surrounding tissues to spur the formation of new blood vessels, which is essential for the aggravation of vascular diseases ${ }^{[31]}$. In experimental studies, LPS has been shown to promote human endothelial cell migration by inducing the activation of related inflammatory cytokines such NF-KB and IL-8, which is the main tissue-derived chemoattractant for leukocytes and partly contributes to the interaction of leukocytes with ECs ${ }^{[32,33]}$. Based on these reports, we examined the effects of COS on LPSinduced HUVEC migration and monocyte (U937 cell line) adhesion to HUVECs. As expected, LPS stimulation not only promoted HUVEC migration but also intensified U937 cell adhesion to HUVECs, and these effects were reversed by COS pretreatment. Considering the excessive production of IL-8 in HUVECs challenged by LPS, it can be speculated that COS might lessen LPS-induced HUVEC migration and U937 cell adhesion through inhibition of IL-8 production. Conversely, the study by Park et al provided a different observation that chitosan treatment elicited neutrophil migration, which was enhanced with an increasing degree of $\mathrm{N}$-acetylation of chitosan ${ }^{[34]}$. As the $N$-acetylation degree of COS $(<1 \mathrm{kDa})$ used in the present study is below $5 \%$, perhaps it is the different $\mathrm{N}$-acetylation degree and different molecular weight between chitosan and COS that led to the opposite pharmaceutical effects in the two observations.

Among the known cell signaling pathways, NF-кB, and AP-1 are two well-studied transcription factors and have been demonstrated to induce the production of inflammatory cytokines such as IL-8, IL-6, and adhesion molecules ${ }^{[27,35]}$. In resting cells, NF-kB exists in its canonical form as a p50/p65 heterodimer bound to the inhibitor factor-кB (ІкB) in the cytoplasm $^{[36]}$. In response to extracellular stimulation such as by LPS and TNF- $\alpha$, the degradation of ІкB through proteolysis is initiated, which allows for the translocation of NF-kB from the cytoplasm into the nucleus, where it activates the transcription of target genes ${ }^{[4]}$. AP-1, a heterodimer formed by the products of the c-Fos and c-Jun, is another nuclear transcription factor that is involved in inflammation by binding to the upstream promoters of inflammatory cytokines ${ }^{[37]}$. In this study, COS pretreatment suppressed LPS-induced NF-KB and AP-1 activation by reducing the levels of both transcription factors in the nuclei of HUVECs, from which we therefore speculate that the inhibitory effect of COS on IL-8 over-production in LPSinduced HUVECs may result from the suppression of NF- $\mathrm{kB}$ and AP-1 activation.

Among the cell signaling pathways in ECs, p38 MAPK and PI3K/Akt are reported to act upstream of NF-KB and $\mathrm{AP}-1$. In the case of TNF- $\mathrm{a}-\mathrm{induced} \mathrm{I} \mathrm{K} \mathrm{B}$ degradation and subsequent NF-KB activation in HUVECs, a pivotal role for p38 MAPK has been identified ${ }^{[21]}$. Additionally, p38 activity is necessary for the recruitment of AP-1, which subsequently promotes IL-8 expression ${ }^{[38]}$. Studies by Isoda et al and Kim et al showed that the release of pro-inflammatory cytokines was positively related to the activation of NF-KB and AP-1 through the up-regulation of phosphorylated PI3K and Akt levels ${ }^{[27,39]}$. Hence, we assessed the effect of COS on LPSinduced phosphorylation of p38 MAPK and Akt. Our findings suggest that COS pretreatment suppressed the phosphorylation of these two pro-inflammatory kinases in HUVECs challenged by LPS. More importantly, the LPS-induced IL-8 mRNA expression was partially, but significantly, inhibited by pretreatment with specific inhibitors of p38 MAPK (SB203580) and PI3K (LY294002), implying a critical role for both signaling pathways in the regulation of IL-8 expression ${ }^{[40,41]}$. On the other hand, the partial effects of SB203580 and LY294002 also revealed potential roles for other signaling pathways. Taken together, these results might indicate that COS blocked LPSinduced signal transduction of IL-8 in HUVECs at least partly 
by suppressing the phosphorylation of p38 MAPK and Akt and the translocation of NF-KB and AP-1.

Binding of COS to a specific receptor is thought to be a prerequisite for enhancing cell activation ${ }^{[42]}$. In studies by Feng et al, oligochitosan was found to interact with the mannose receptor in macrophages and was subsequently internalized into cells ${ }^{[43]}$. Regretfully, it remains to be determined whether COS can also be internalized into HUVECs and, if so, which membrane molecules are involved in COS-mediated inhibition of pro-inflammatory cytokine production. These puzzling presumptions indicate that the action of COS on endothelial cells may be complex, and further efforts are required to explore the underlying mechanisms by which COS exert their anti-inflammatory effects.

In conclusion, our investigation demonstrated that COS exerted an inhibitory effect on LPS-induced IL-8 expression in HUVECs at the transcriptional and translational levels. Furthermore, COS inhibited LPS-induced HUVEC migration and U937 monocyte adhesion to HUVECs. Signal transduction studies suggest that COS act by interfering with the phosphorylation of p38 MAPK and Akt and the translocation of NF-kB and AP-1. Our findings underscore a role of COS in ameliorating endothelial dysfunction by exogenous insults to the vasculature.

\section{Acknowledgements}

This work was supported by the National Programs for High Technology Research and Development (863 Programs, 2006AA100313 and 2007AA10Z343), the Major National SciTech Projects (2009ZX09501-011) and by the Science Fund of Chongqing Medical University, China (XBZD200806).

\section{Author contribution}

Yu-guang DU and Chao YU designed the experiments; Hongtao LIU, Pei HUANG, and Pan MA performed the research; Qi-shun LIU analyzed the data; and Hong-tao LIU wrote the paper.

\section{References}

1 Schumann RR, Pfeil D, Lamping N, Kirschning C, Scherzinger G, Schlag $P$, et al. Lipopolysaccharide induces the rapid tyrosine phosphorylation of the mitogen-activated protein kinases erk-1 and p38 in cultured human vascular endothelial cells requiring the presence of soluble CD14 Blood; 1996; 87: 2805-14.

2 Zhu YM, Azahri NS, Yu DC, Woll PJ. Effects of COX-2 inhibition on expression of vascular endothelial growth factor and interleukin-8 in lung cancer cells. BMC Cancer 2008; 8: 218.

3 Anand AR, Cucchiarini M, Terwilliger EF, Ganju RK. The tyrosine kinase Pyk2 mediates lipopolysaccharide-induced IL-8 expression in human endothelial cells. J Immunol 2008; 180: 5636-44.

4 Oh GS, Pae HO, Choi BM, Lee HS, Kim IK, Yun YG, et al. Penta-Ogalloyl-beta- $D$-glucose inhibits phorbol myristate acetate-induced interleukin-8 [correction of intereukin-8] gene expression in human monocytic U937 cells through its inactivation of nuclear factorkappaB. Int Immunopharmacol 2004; 4: 377-86.

5 Hashimoto S, Gon Y, Matsumoto K, Maruoka S, Takeshita I, Hayashi $\mathrm{S}$, et al. Selective inhibitor of p38 mitogen-activated protein kinase inhibits lipopolysaccharide-induced interleukin-8 expression in human pulmonary vascular endothelial cells. J Pharmacol Exp Ther 2000; 293: 370-5.

6 Harish Prashanth KV, Tharanathan RN. Depolymerized products of chitosan as potent inhibitors of tumor-induced angiogenesis. Biochim Biophys Acta 2005; 1722: 22-9.

7 Mendis E, Kim MM, Rajapakse N, Kim SK. An in vitro cellular analysis of the radical scavenging efficacy of chitooligosaccharides. Life Sci 2007; 80: 2118-27.

8 Xu JG, Zhao XM, Han XW, Du YG. Antifungal activity of oligochitosan against Phytophthora capsici and other plant pathogenic fungi in vitro. Pestic Biochem Phys 2007: 220-8.

9 Nam KS, Shon YH. Suppression of metastasis of human breast cancer cells by chitosan oligosaccharides. J Microbiol Biotechnol 2009; 19: 629-33.

10 Yuan WP, Liu B, Liu CH, Wang XJ, Zhang MS, Meng XM, et al. Antioxidant activity of chito-oligosaccharides on pancreatic islet cells in streptozotocin-induced diabetes in rats. World J Gastroenterol 2009; 15: $1339-45$.

11 Song S, Zhou F, Nordquist RE, Carubelli R, Liu H, Chen WR. Glycated chitosan as a new non-toxic immunological stimulant. Immunopharmacol Immunotoxicol 2009; 31: 202-8.

12 Villiers C, Chevallet M, Diemer H, Couderc R, Freitas H, Van Dorsselaer $A$, et al. From secretome analysis to immunology: chitosan induces major alterations in the activation of dendritic cells via a TLR4dependent mechanism. Mol Cell Proteomics 2009; 8: 1252-64.

13 Wu GJ, Tsai GJ. Chitooligosaccharides in combination with interferongamma increase nitric oxide production via nuclear factor-kappaB activation in murine RAW264.7 macrophages. Food Chem Toxicol 2007; 45: 250-8.

14 Yoon HJ, Moon ME, Park HS, Im SY, Kim YH. Chitosan oligosaccharide (COS) inhibits LPS-induced inflammatory effects in RAW 264.7 macrophage cells. Biochem Biophys Res Commun 2007; 358: 954-9.

15 Lidington EA, Moyes DL, McCormack AM, Rose ML. A comparison of primary endothelial cells and endothelial cell lines for studies of immune interactions. Transpl Immunol 1999; 7: 239-46.

16 Zhang H, Du Y, Yu X, Mitsutomi M, Aiba S. Preparation of chitooligosaccharides from chitosan by a complex enzyme. Carbohydr Res 1999; 320: 257-60.

17 Dou JL, Tan CY, Du YG, Bai XF, Wang KY, Ma XJ. Effects of chitooligosaccharides on rabbit neutrophils in vitro. Carbohyd Polym 2007; 69: 209-13.

18 Xu QS, Dou JL, Wei P, Tan CY, Yun XJ, Wu YH, et al. Chitooligosaccharides induce apoptosis of human hepatocellular carcinoma cells via up-regulation of Bax. Carbohyd Polym 2008; 71: 509-14.

19 Shen J, DiCorleto PE. ADP stimulates human endothelial cell migration via P2Y1 nucleotide receptor-mediated mitogen-activated protein kinase pathways. Circ Res 2008; 102: 448-56.

20 Madi A, Lakhdari O, Blottière HM, Guyard-Nicodème M, Le Roux K, Groboillot A, et al. The clinical Pseudomonas fluorescens MFN1032 strain exerts a cytotoxic effect on epithelial intestinal cells and induces Interleukin-8 via the AP-1 signaling pathway. BMC Microbiol 2010; 10: 215.

21 Bowie AG, O'Neill LA. Vitamin C inhibits NF-kappa B activation by TNF via the activation of p38 mitogen-activated protein kinase. J Immunol 2000; 165: 7180-8.

22 Dauphinee SM, Karsan A. Lipopolysaccharide signaling in endothelial cells. Lab Invest 2006; 86: 9-22.

23 Huang NL, Chiang SH, Hsueh CH, Liang YJ, Chen YJ, Lai LP. Metformin inhibits TNF-alpha-induced IkappaB kinase phosphorylation, IkappaBalpha degradation and IL-6 production in endothelial cells through 
PI3K-dependent AMPK phosphorylation. Int J Cardiol 2009; 134: 169-75.

24 Papadopoulou C, Corrigall V, Taylor PR, Poston RN. The role of the chemokines MCP-1, GRO-alpha, IL-8 and their receptors in the adhesion of monocytic cells to human atherosclerotic plaques. Cytokine 2008; 43: 181-6.

25 Seino Y, Ikeda U, Ikeda M, Yamamoto K, Misawa Y, Hasegawa T, et al. Interleukin 6 gene transcripts are expressed in human atherosclerotic lesions. Cytokine1994; 6: 87-91.

26 Bierhaus A, Chen J, Liliensiek B, Nawroth PP. LPS and cytokineactivated endothelium. Semin Thromb Hemost 2000; 26: 571-87.

27 Isoda K, Young JL, Zirlik A, MacFarlane LA, Tsuboi N, Gerdes N, et al. Metformin inhibits proinflammatory responses and nuclear factorkappaB in human vascular wall cells. Arterioscler Thromb Vasc Biol 2006; 26: 611-7.

28 Li WG, Gavrila D, Liu X, Wang L, Gunnlaugsson S, Stoll LL, et al. Ghrelin inhibits proinflammatory responses and nuclear factorkappaB activation in human endothelial cells. Circulation 2004; 109 : 2221-6.

29 Galley HF, Dhillon JK, Paterson RL, Webster NR. Effect of ciprofloxacin on the activation of the transcription factors nuclear factor kappaB, activator protein-1 and nuclear factor-interleukin-6, and interleukin-6 and interleukin-8 mRNA expression in a human endothelial cell line. Clin Sci (Lond) 2000; 99: 405-10.

30 Baggiolini M, Clark-Lewis I. Interleukin-8, a chemotactic and inflammatory cytokine. FEBS Lett 1992; 307: 97-101.

31 Folkman J. Tumor angiogenesis: therapeutic implications. N Engl J Med 1971; 285: 1182-6.

32 Kim TH, Bae JS. Ecklonia cava extracts inhibit lipopolysaccharide induced inflammatory responses in human endothelial cells. Food Chem Toxicol 2010; 48: 1682-7.

33 Jang SI, Kim YJ, Kim HJ, Lee JC, Kim HY, Kim YC, et al. Scoparone inhibits PMA-induced IL-8 and MCP-1 production through suppression of NF-kappaB activation in U937 cells. Life Sci 2006; 78: 2937-43.

34 Park CJ, Gabrielson NP, Pack DW, Jamison RD, Wagoner Johnson AJ.
The effect of chitosan on the migration of neutrophil-like HL60 cells, mediated by IL-8. Biomaterials 2009; 30: 436-44.

35 Abdel-Malak NA, Srikant CB, Kristof AS, Magder SA, Di Battista JA, Hussain SN. Angiopoietin-1 promotes endothelial cell proliferation and migration through AP-1-dependent autocrine production of interleukin-8. Blood 2008; 111: 4145-54.

36 Luppi P, Cifarelli V, Tse H, Piganelli J, Trucco M. Human C-peptide antagonises high glucose-induced endothelial dysfunction through the nuclear factor-kappaB pathway. Diabetologia 2008; 51: 1534-43.

37 Allison CC, Kufer TA, Kremmer E, Kaparakis M, Ferrero RL. Helicobacter pylori induces MAPK phosphorylation and AP-1 activation via a NOD1-dependent mechanism. J Immunol 2009; 183: 8099-109.

38 Ferreiro I, Barragan M, Gubern A, Ballestar E, Joaquin M, Posas F. The p38 SAPK is recruited to chromatin via its interaction with transcription factors. J Biol Chem 2010; 285: 31819-28.

$39 \mathrm{Kim}$ JE, Son JE, Jung SK, Kang NJ, Lee CY, Lee KW, et al. Cocoa polyphenols suppress TNF- $\alpha$-induced vascular endothelial growth factor expression by inhibiting phosphoinositide 3-kinase (PI3K) and mitogen-activated protein kinase kinase-1 (MEK1) activities in mouse epidermal cells. Br J Nutr 2010; 104: 957-64.

40 Guan SM, Zhang M, He JJ, Wu JZ. Mitogen-activated protein kinases and phosphatidylinositol 3-kinase are involved in Prevotella intermedia-induced proinflammatory cytokines expression in human periodontal ligament cells. Biochem Biophys Res Commun 2009; 386: 471-6.

41 Kuntz S, Kunz C, Rudloff S. Carbonyl compounds methylglyoxal and glyoxal affect interleukin-8 secretion in intestinal cells by superoxide anion generation and activation of MAPK p38. Mol Nutr Food Res 2010; 54: 1458-67.

42 Porporatto C, Bianco ID, Riera CM, Correa SG. Chitosan induces different $L$-arginine metabolic pathways in resting and inflammatory macrophages. Biochem Biophys Res Commun 2003; 304: 266-72.

43 Feng J, Zhao L, Yu Q. Receptor-mediated stimulatory effect of oligochitosan in macrophages. Biochem Biophys Res Commun 2004; 317: 414-20. 